\title{
Compressive Strength and Surface Absorption of High Strength Silica Fume Concrete Under Different Curing Conditions
}

\author{
S.K. Al-Oraimi*, A.W. Hago, H.F. Hassan and R.Taha \\ Department of Civil and Architectural Engineering, Sultan Qaboos University, P.O. Box 33, Al-Khoud 123, Muscat, Oman
}

Received 17 September 2005; accepted 15 April 2006

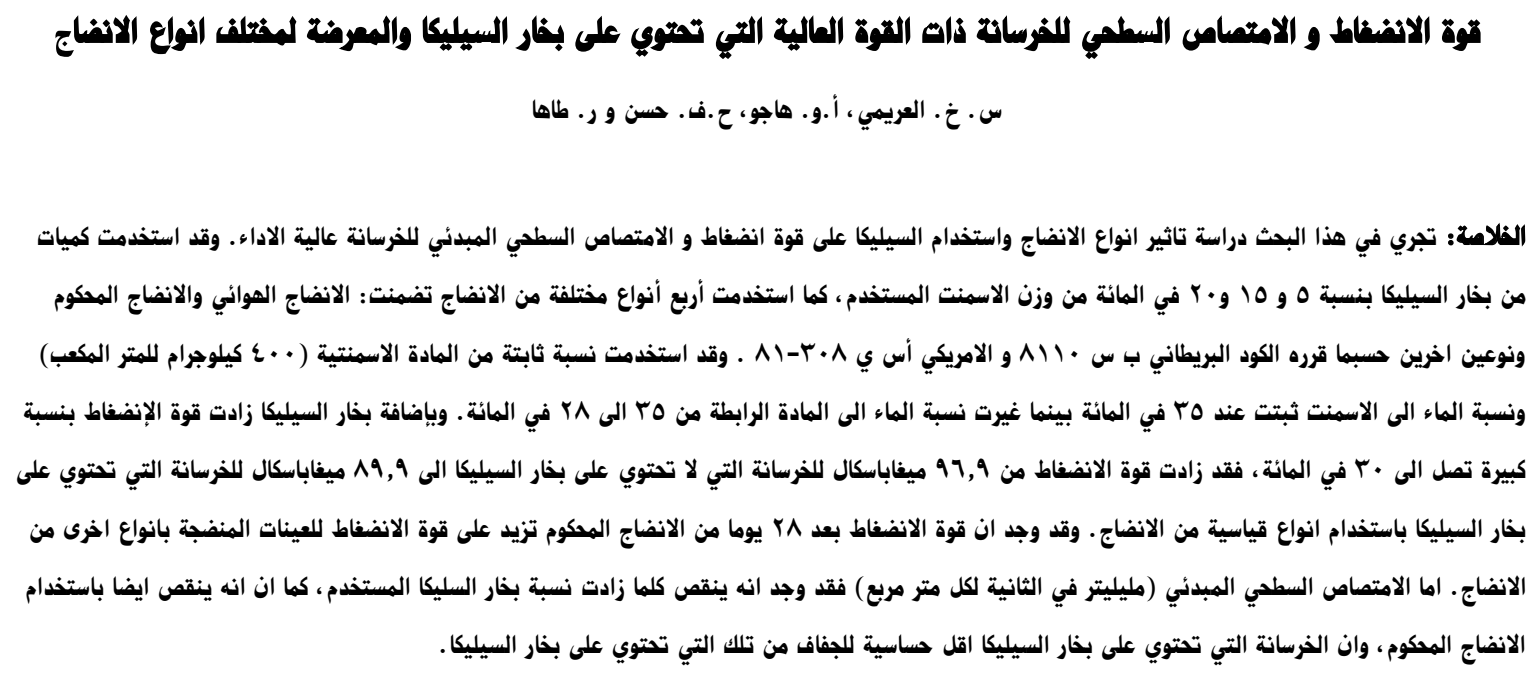

الهغرادت الهثاهية: الانضاج، الخرسانة عالية القوة، قوة الانضفاط، قوة الانحناء، قوة الانشطار، الامتصاص السطي المبدئي، بخار سيليكا.

\begin{abstract}
The effect of curing conditions and silica fume replacement on the compressive strength and the initial surface absorption of high performance concrete is reported. The silica fume contents were 5, 10, 15 and 20\%, by weight of cement. Four different curing conditions were used: air curing, control curing and two other curing conditions recommended by BS8110 and ACI308-81. The cementitious material (binder) content was constant $\left(400 \mathrm{~kg} / \mathrm{m}^{3}\right)$; the water/cement (w/c) ratio was also maintained at a constant value of 0.35 ; while the water/binder $(\mathrm{w} / \mathrm{b})$ ratio ranged from 0.35 to 0.28 . The addition of silica fume enhanced the compressive strength significantly up to $30 \%$. The 28-day compressive strength was found to be 69.9 MPa without silica fume and it was determined to be $89.9 \mathrm{MPa}$ with silica fume under the standard curing condition. The 28-day compressive strength results under the control curing condition were found to be higher than the compressive strength for specimens cured under other curing conditions. The surface absorption $\left(\mathrm{ml} / \mathrm{m}^{2} . \mathrm{s}\right)$ was found to decrease as the percentage replacement of silica fume was increased. Control curing also decreases the surface absorption of water compared with air curing. Concrete with silica fume was less sensitive to drying than that without silica fume.
\end{abstract}

Keywords: Curing; High strength concrete; Compressive strength; Flexural strength; Splitting strength; Initial surface absorption; Silica fume

\section{Introduction}

High performance concrete (HPC) represents a rather recent development in concrete materials technology. HPC is a concrete with properties which satisfy the performance criteria. Generally, concrete with higher strength and attributes superior to conventional concrete is desirable in the construction industry. Usually HPC is defined in terms of strength and durability (Fidjestol, 1993). Foster (1994) defined HPC as "a concrete made with appropriate materials combined according to a

*Corresponding author’s e-mail: aloraimi@squ.edu.om selected mix design and properly mixed, transportedplaced, consolidated, and cured so that the resulting concrete will give excellent performance in the structure in which it will be exposed, and with the loads to which it will be subjected for its design life".

The strategy to produce HPC is to use mineral admixtures such as silica fume, as a partial cement replacement. Silica fume reacts to form hydration products such that when introduced in the Portland cement paste it can partially replace Portland cement. Silica fume has been used more and more in concrete due to its benefits in terms of strength and durability. There is a wealth of information 
in the literature related to the effect of different silica fume replacement on concrete properties. Silica fume continues to be a popular element of high performance concrete. Not only does it provide an extremely rapid pozzolanic reaction, but also investigators including Detwiler and Mehta ((1989), and Goldman and Bentur (1998) found that its very fine

size also appears to provide a beneficial contribution to concrete. Those researchers examined the effect of silica fume on mechanical behaviour of concrete. Luther (1989) in his review examined durability effects, while Fidjestol (1993) and Khayat and Aitcin (1992) have provided general reviews of the effects. All those investigators confirm findings that silica fume tend to improve both mechanical properties and durability.

Bentur et al. (1998) reported that the strength of silica fume concrete is greater than that of silica fume paste. They attributed it to the change in the role of aggregate as an inert filler, but, due to the presence of the weak interfacial zone, composite concrete is weaker than cement paste. A similar conclusion made by Toutanji and ElKorchi (1995) was that the increase in compressive strength of mortar containing silica fume as a partial replacement for cement, greatly contributes to strengthening the bond between the cement paste and aggregate. They reported that partial replacement of cement by silica fume and the addition of superplasticizers increase the strength of mortar, but have no influence on the strength of cement paste.

On the other hand, some investigators have reported that the increase in concrete strength is due, in great part, to a higher quality of the cement paste matrix. Cong et al. (1992) found that the replacement of cement by silica fume (up to 18\%) and the addition of superplasticizers increase the strength of cement paste. Darwin et al. (1989) found that the strength of both cement paste and mortar increases when $15 \%$ of the cement is replaced by silica fume.

Meeks and Carino (1999) concluded that current practice and standards are based on studies related primarily to strength development characteristics of conventional concrete. Most HPC, however, are fundamentally different from conventional concrete, because they typically have a low water/binder ratio (w/b) and one or more admixtures. Since the composition of a high performance concrete differs from conventional mixtures, early age characteristics of the hydrating paste will also differ. Therefore, existing curing practices may not be optimal for high performance concrete. A better understanding is needed of the role of an external supply of moisture and of the adequacy of membrane-forming compounds when a low w/b is used.

One of the most controversial topics that emerged from the literature review by Meeks and Carino (1999) concerns the sensitivity of various properties of high performance concrete to different curing conditions. Some researchers have reported that high performance concrete is more sensitive to the details of curing than normal concrete; whereas others have found the opposite to be true, at least for some properties. These differences may be attributed to the different experimental procedures that have been used. For example, Hasni et al. (1994) reported that the use of silica fume makes high performance concrete more sensitive to different curing methods when considering both strength and durability properties. In addition, they Hasni et al. (1994) reported that high performance concrete with silica fume is more sensitive to different curing methods than normal concrete for characteristics such as compressive strength and flexural strength, depth of carbonation, and microcracking. With respect to resistance to penetration of chloride ions, results showed that high performance concrete with and without silica fume, as well as normal concrete, were not sensitive to the curing method.

Research on the effect of silica fume on the mechanical properties of concrete is still evolving. Curing effects on normal concrete have been studied extensively, and results have been established (Meeks et al. (1999), however, the effect of different curing procedures on silica fume concrete still needs more research. The purpose of the research reported here is to improve our knowledge about the role of silica fume on enhancing the mechanical properties of concrete under different curing conditions. Initial Surface Absorption Tests (ISAT) were also carried out on concrete cubes to study the effect of silica fume on the permeability of concrete.

\section{Materials}

\subsection{Cement}

The cement used in this study was ordinary Portland cement (OPC) obtained from a single batch conforming to the Omanian Standard Specification (OS 7:2001 OPC) [15]. Physical and chemical properties of this cement as supplied by the manufacturer are given in Tables 1 and 2, respectively.

\subsection{Aggregate}

The fine aggregate was crushed gravel corresponding to Zone 2 grading according to OS 2:1982 [16]. It was purchased from a nearby crusher in Al-Khodh Area which is from the same batch. The coarse aggregate was a crushed limestone supplied locally and has a maximum size of $10 \mathrm{~mm}$.

\subsection{Silica Fume}

Silica fume consists primarily of amorphous (non-crystalline) silicon dioxide $\left(\mathrm{SiO}_{2}\right)$. The individual particles are extremely small, approximately $1 / 100^{\text {th }}$ the size of an average cement particle. The silica fume (Emsac 500s) was used in these experimental studies and it was added to the mix in a powder form. The quality of silica fume is specified by ASTM C1240-03a. Physical and chemical properties of silica fume as supplied by the manufacturer are given in Tables 1 and 2, respectively.

\subsection{Superplasticizer}

The superplasticizer (Conplast SP430) conforms to BS 5075: Part 3 and ASTM C494 as Type A and Type F, 
Table 1. Physical properties of ordinary Portland cement and silica fume

$\begin{array}{lcc}\begin{array}{c}\text { Material/Test } \\ \text { Type }\end{array} & \begin{array}{c}\text { Ordinary } \\ \text { Portland } \\ \text { Cement } \\ \text { Specific }\end{array} & \text { Silica fume } \\ \text { Gravity } & 3.05 & 2.2 \\ \text { Fineness } & 3,357 & 200,000 \\ \left(\mathrm{~cm}^{2} / \mathrm{g}\right) & & \\ \text { Initial Setting } & 110 & - \\ \text { (minutes) } & & \end{array}$

Table 2. Chemical composition of ordinary Portland cement and silica fume

$\begin{array}{lcc}\text { Component } & \begin{array}{l}\text { Ordinary } \\ \text { Portland Cement } \\ \text { (\%) }\end{array} & \begin{array}{l}\text { Silica fume } \\ \text { (\%) }\end{array} \\ \mathrm{SiO}_{2} & 21.94 & 93.2 \\ \mathrm{Al}_{2} \mathrm{O}_{3} & 4.95 & 0.44 \\ \mathrm{Fe}_{2} \mathrm{O}_{3} & 3.74 & 0.20 \\ \mathrm{CaO} & 62.33 & \text { NA } \\ \mathrm{MgO} & 2.08 & 0.81 \\ \mathrm{SO}_{3} & 2.22 & 0.45 \\ \mathrm{~K}_{2} \mathrm{O} & 0.56 & 1.28 \\ \mathrm{Na}_{2} \mathrm{O} & 0.32 & 0.59 \\ \mathrm{TiO}_{2} & 0.17 & \mathrm{NA} \\ \mathrm{Mn}_{2} \mathrm{O}_{3} & 0.05 & \mathrm{NA} \\ \mathrm{Cl} & 0.01 & \mathrm{NA} \\ \mathrm{LOI} & 1.78 & \text { NA } \\ \mathrm{IR} & 0.24 & \text { NA } \\ \mathrm{C} & \mathrm{NA} & 0.55 \\ \mathrm{C} \text { (isolated) } & \text { NA } & 0.41 \\ \mathrm{pH} & \mathrm{NA} & 7.9 \\ \mathrm{SI} \text { (isolated) } & \mathrm{NA} & 0.29 \\ \mathrm{SIC} & \mathrm{NA} & 0.50\end{array}$

NA: Not applicable

depending on dosage used. Conplast SP430 is a chloride free, based on selected sulphonated naphthalene polymers, which had $40 \%$ active solids in solution. It was supplied as a brown solution, which instantly disperses in water.

\section{Experimental Program}

\subsection{Mix Design}

The mix proportions chosen for this study were select- ed from a range of trial mixes and are given in Table 3. The dry constituents were mixed in the rotating pan mixer with a speed of $40 \mathrm{rpm}$. The standardized mixing procedure was as follows: cement, sand and silica fume were mixed first; then water and coarse aggregate were added; and finally superplasticizers were introduced in the mix to achieve the desired workability. The overall mixing time was about 4 minutes.

From each mix, thirty $100 \mathrm{~mm}$ cubes, three $100 \times 100 \times 500 \mathrm{~mm}$ prisms and three $150 \times 300 \mathrm{~mm}$ cylinders were cast. All specimens were compacted by means of a vibrating table. The frequency of the vibrating table was 2280 cycles/minute and all specimens were vibrated for 60 seconds. The specimens were covered with a wet burlap and plastic covers thirty minutes after casting, and later demoulded after 24 hours. The specimens were then cured as described below.

\subsection{Curing Conditions}

Four different types of curing regimes, Table 4 were chosen to study the effect of different curing conditions on the compressive strength and surface absorption of high performance concrete. The curing conditions of $\mathrm{C} 2$ and C3 conformed to that recommended by BS 8110 and ACI 308-81, respectively for ordinary Portland cement (Type 1 ), while $\mathrm{C} 4$ is the control curing which is a standard practice in our concrete laboratory. The room temperature was $25^{\circ} \mathrm{C}$ and the relative humidity was $60 \%$ for C4 curing. For all curing methods, curing in water was done prior to curing in air. The temperature in the laboratory was $25^{\circ} \mathrm{C}$ while the relative humidity varied from 35 to $60 \%$ during the time of curing and testing. All specimens were oven dried before testing for water surface absorption. The oven temperature was $100^{\circ} \mathrm{C}$ and the specimens were oven dried for 24 hours.

\subsection{Testing Procedure}

The compressive strength was obtained by testing 100 mm cubes according to the BS 1881: Part 116: 1983 (17). The cubes were tested in a $3000 \mathrm{kN}$ testing machine at a rate of $2.5 \mathrm{kN} / \mathrm{s}$. The splitting tensile strength was tested using 150x300 mm cylinders, according to BS 1881: Part 117: 1983 (18). The flexural strength was tested using 100x100x500 mm prisms according to the BS 1881: Part 118: 1983 (19). All these tests were conducted at the age of 28 days.

The Initial Surface Absorption Tests (ISAT) were conducted in accordance with BS 1881: Part 208: 1996 (20) on all specimens after 2 months from the date of casting. The Initial Surface Absorption test was performed as an indicator for the durability of the mixes. The concrete cubes were initially oven-dried. A cap was attached to the concrete surface. This cap was connected to a reservoir with a water pressure head of $200 \mathrm{~mm}$. The cap was also connected to a horizontal capillary tube. Water was allowed to penetrate the concrete surface from the reservoir into the cap. At the end of 0, 30, 60 and 120 minutes, the reservoir flow was closed and the water was allowed 
Table 3. Details of mix proportions

\begin{tabular}{|c|c|c|c|c|c|}
\hline \multirow[t]{2}{*}{ Constituents } & \multicolumn{5}{|c|}{$\begin{array}{c}\text { Quantities } \\
\mathbf{k g} / \mathrm{m}^{3}\end{array}$} \\
\hline & Mix. 1 & Mix. 2 & Mix. 3 & Mix. 4 & Mix. 5 \\
\hline Cement & 400 & 380 & 360 & 340 & 320 \\
\hline Fine aggregate & 710 & 710 & 710 & 710 & 710 \\
\hline Coarse aggregate & 1190 & 1190 & 1190 & 1190 & 1190 \\
\hline Water & 140 & 133 & 126 & 119 & 112 \\
\hline Silica fume & -- & 20 & 40 & 60 & 80 \\
\hline Superplastisizer & $10 \mathrm{ltr}$ & 11 ltr & 12 ltr & 13 ltr & 15 ltr \\
\hline $\mathrm{W} / \mathrm{C}$ & 0.35 & 0.35 & 0.35 & 0.35 & 0.35 \\
\hline $\mathrm{W} / \mathrm{b}$ & 0.35 & 0.33 & 0.32 & 0.30 & 0.28 \\
\hline
\end{tabular}

Table 4. Curing conditions

$\begin{array}{lcccc}\text { Condition } & \begin{array}{c}\text { Days in } \\ \text { Mold }\end{array} & \begin{array}{c}\text { Days in } \\ \text { water }\end{array} & \begin{array}{c}\text { Days in Air } \\ \text { Compressive }\end{array} \\ \text { C1 } & 1 & 0 & 27 & 58-64 \\ \text { C2 } & 1 & 2 & 25 & 56-62 \\ \text { C3 } & 1 & 6 & 21 & 52-58 \\ \text { C4 } & 1 & 27 & 0 & 31-37\end{array}$

to penetrate the concrete surface from the capillary tube. The test gives the water flow $\left(\mathrm{ml} / \mathrm{m}^{2} . \mathrm{sec}\right)$ into the surface of the dry cube specimen using the calibration of the capillary tube.

\section{Results and Discussion}

\subsection{Strength}

\subsubsection{Compressive Strength}

The compressive strength results for the five mixes are presented graphically in Fig. 1. The compressive strength under the control curing condition (C4) increased as the water/binder (w/b) ratio decreased. Similar trends were also observed for the other three types of curing conditions. The use of silica fume as a replacement of cement increased the compressive strength of concrete up to $30 \%$. The increase in compressive strength is due to the high fineness of silica fume, which allows the material to act as a filler and to provide an additional strength by reducing the void content in the cement paste matrix. Increasing

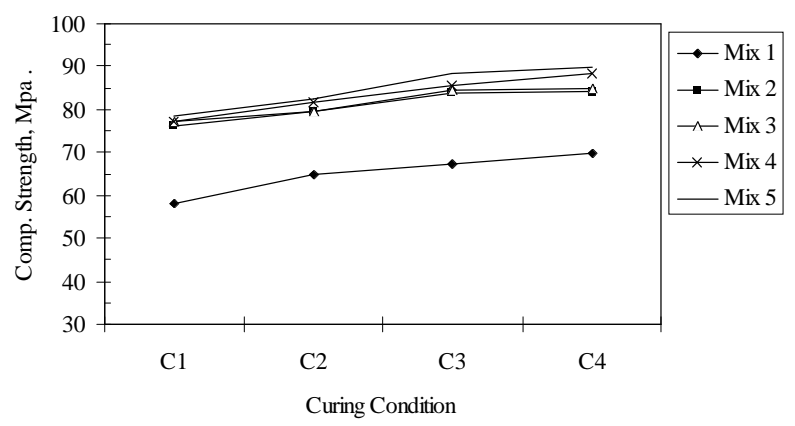

Figure 1. Relationship between 28-days compressive strength and curing conditions the silica fume replacement beyond 15\% will not affect the compressive strength too much. Considering the cost of silica fume and the effect of its percentage replacement on the compressive strength, one would expect that a 10$15 \%$ of silica fume replacement is optimum.

The effect of moist curing condition on the compressive strength of concrete is also presented in Fig. 1. The concrete cubes with curing conditions of $\mathrm{C} 1, \mathrm{C} 2$, and C3 had a lower strength value compared to those with the control moist curing condition C4, for concretes both with and without silica fume. This is expected, since concrete with a prolonged moist curing should have a higher strength. It is also observed from Fig. 1 that concrete with silica fume seems to be less sensitive to drying than that without silica fume. This is because of the rapid reaction happening between the silica fume and the calcium hydroxide released by $\mathrm{C}_{3} \mathrm{~S}$ and $\mathrm{C}_{2} \mathrm{~S}$ hydration.

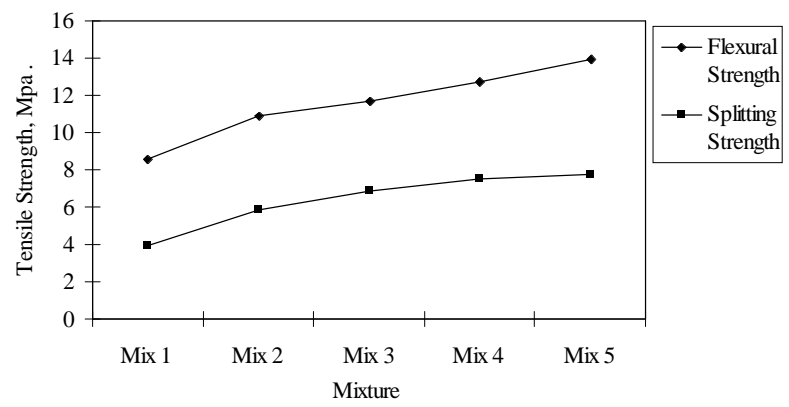

Figure 2. Tensile strength at 28-days for different mixes

\subsubsection{Flexural Indirect Tensile Strength}

The 28-day flexural and splitting tensile strength results are presented graphically in Fig. 2. These specimens were cured under the curing condition C4 (control moit curing) 
to investigate the effect of silica fume on them. The flexural and splitting tensile strength varied from 8.6 to 13.9 $\mathrm{MPa}$ and from 3.9 to $7.8 \mathrm{MPa}$, respectively. The tensile/compressive strength ratio was found to increase as the percentage replacement of silica fume was increased. From Fig. 2, it is also clear that the tensile strength increases as the compressive strength increases.

\subsection{Water Absorption}

The water absorption of concrete was investigated by the Initial Surface Absorption Test (ISAT). The test results are presented in Figs. 3, 4, 5 and 6 for the four curing conditions C1, C2, C3 and C4, respectively. The results obtained for condition 1 (C1), which is air curing, is shown graphically in Fig. 3. It is clear that the flow of

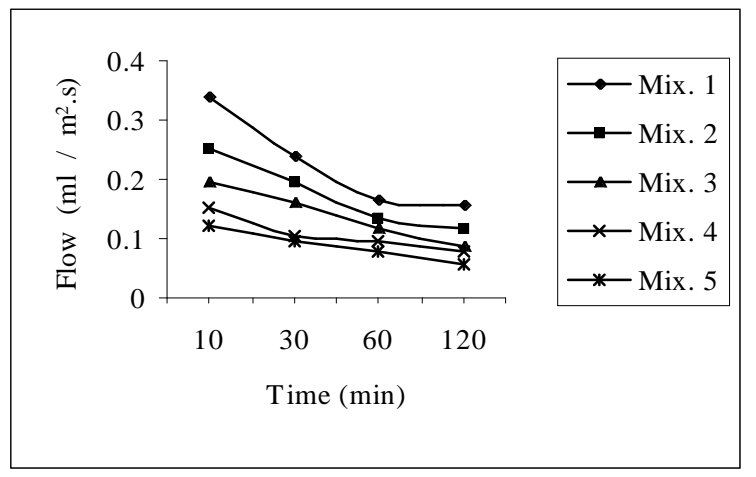

Figure 3. Flow versus time for different mixes (condition 1 C1)

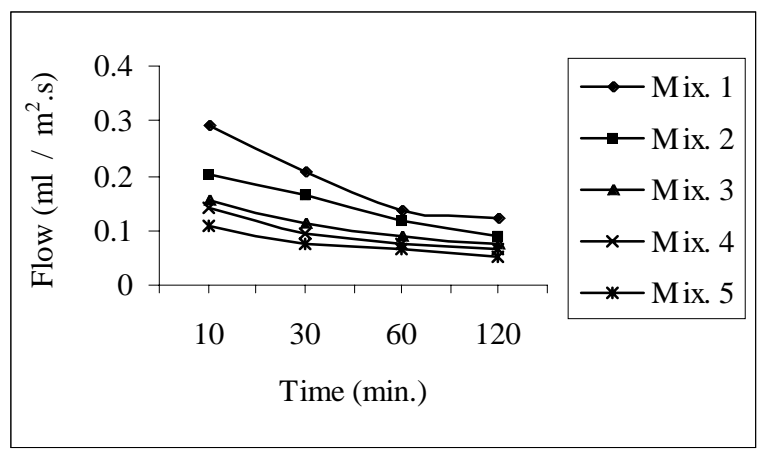

Figure 4. Flow versus time for different mixes (Condition 2 C2)

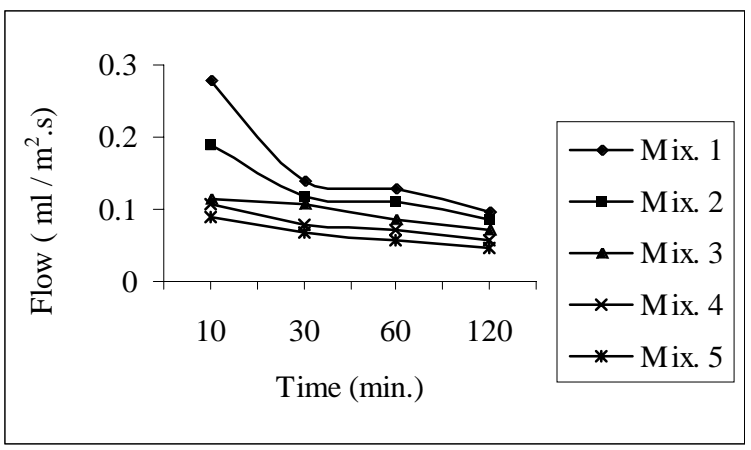

Figure 5. Flow versus time for different mixes (Condition 3 C3) water decreased as the percentage replacement of silica fume was increased. This is expected since the silica fume act as a microfiller and its extreme fineness allows it to fill the microscopic voids between cement particles, which greatly reduces the permeability.

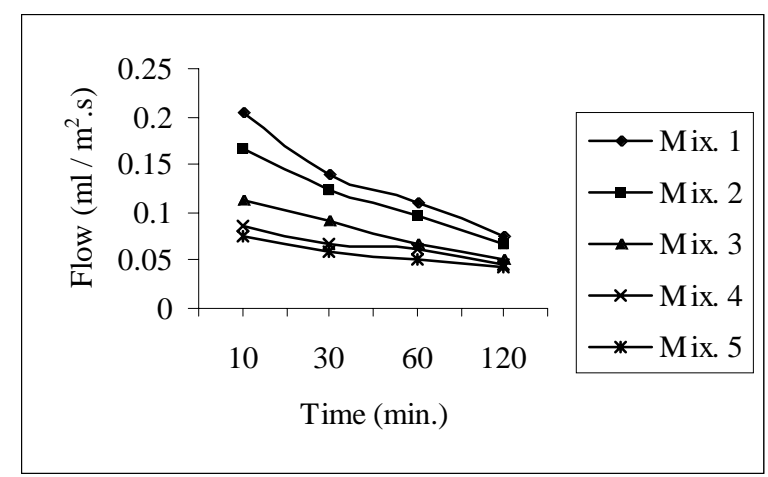

Figure 6. Flow versus time for different mixes (Condition 4 C4)

The results obtained for condition 4 (C4), which is control moist curing, is shown graphically in Fig. 6. The conclusions drawn for condition 1 (C1) apply also to condition 4 (C4). Surface permeability is reduced more with moist curing rather than air curing. Almost the same effect was produced by the addition of silica fume.

The results obtained for specimens under curing condition 2 (C2) and curing condition 3 (C3) are presented graphically in Figs. 4 and 5, respectively. Here it is also clear that the flow of water decreased as the percentage replacement of silica fume was increased. The flow values obtained for curing condition 3 (C3) were lower than those obtained for curing condition 2 (C2). This was due to the fact that pores in specimens cured under curing condition 3 (C3) became smaller due to the higher bond between the cement paste and the aggregate.

\section{Conclusions}

From the experimental work conducted in this study, it may be concluded that:-

1. The compressive strength of concrete increases as the water/binder (w/b) ratio decreases.

2. The replacement of cement by silica fume increases the compressive strength significantly up to $30 \%$.

3. Examining the compressive strength results, it was clear that concrete prepared with silica fume was less sensitive to air curing compared to the concrete prepared without silica fume.

4. It is optimum to use silica fume in the range of 10$15 \%$ as a replacement for cement.

5. Concrete with silica fume has a lower surface absorptivity than concrete without silica fume.

6. Concrete cured under the moist curing condition had lower values of surface absorptivity compared to other curing conditions. Concrete cured in air had the highest surface absorptivity. 
7. Further investigation using $x$-ray or electron scanning microscopy is recommended to provide visual assessment of the effect of silica fume on the microstructure of concrete.

\section{Acknowledgments}

The authors would like to express their thanks to Sultan Qaboos University for providing financial support to this project under Grant No. IG/ENG/CIVL/03/02.

\section{References}

BS 1881: Part 116: 1983, "Method for Determination of Compressive Strength of Concrete Cubes," British Standard Institution.

BS 1881: Part 117: 1983, "Method for Determination of Tensile Splitting Strength," British Standard Institution.

BS 1881: Part 118: 1983, "Method for Determination of Flexural Strength," British Standard Institution.

BS 1881: Part 208: 1996, "Recommendations for the Determination of the Initial Surface Absorption of Concrete," British Standard Institution.

Bentur, A., Goldman, A. and Cohen, M.D., 1998, "The Contribution of the Transition Zone to the Strength of High Quality Silica Fume Concrete," Proc Mater Res Soc. pp. 114: 97-102.

Cong, X., Gong, S., Darwin, D. and McCable, S., 1992, "Role of Silica Fume in Compressive Strength of Cement Paste, Mortar, and Concrete," ACI Mater J, Vol. 89(4), pp. 375-387.

Darwin, D., Shen, Z. and Harch, S., 1989, "Silica Fume, Bond Strength, and the Compressive Strength of Mortar," Proc Mater Res Soc. Vol. 114, pp. 105-110.

Detwiler, R.J. and Mehta, P.K., 1989, "Chemical and Physical Effects of Silica Fume on the Mechanical Behaviour of Concrete," ACI Mater J, Vol. 86(6), pp. 609-614.

Fidjestol, P., 1993, " Applied Silica Fume Concrete," Concrete International, Vol. 15(11), pp. 33-36.
Foster, S.W., 1994, "High Performance Concrete Stretching the Paradigm," Concrete International, Vol. 16(10), pp. 33-34.

Goldman, A. and Bentur, A., 1993, "Influence of Microfillers on Enhancement of Concrete Strength," Cem Con Res, Vol. 23(4), pp. 962-972.

Hasni, L., Gallias, J.L. and Saloman, M., 1994, "Influence of the Curing Method on the Durability of Concrete," Third Intr Conf, Nice, France, SP-145, VM Malhotra, Ed., ACI, Farmington Hills, MI, pp. 131-155.

Khayat, K.H. and Aitcin, P.C., 1992, "Silica Fume in Concrete - An Overview," In: proceeding of the 4th International Conference on the Use of Fly Ash, Silica Fume, Slag and Natural Pozzolans in Concrete, Istanbul, Turkey, pp. 835-872.

Luther, M.D., 1989, "Microsilica (Silica Fume) Concrete Durability in Severe Environment, Structural Materials," Proceeding of the Sessions at ASCE Structures Congress 1989, San Francisco, CA, USA, pp. 95-105.

Meeks, K.W. and Carino, N.J., 1999, "Curing of HighPerformance Concrete: Report of the State-of-the Art," NISTIR 6295, Nat. Inst. Of Stds. And Tech., Gaithersburg, MD.

Mindess, S., 1994, "Materials Selection, Proportioning and Quality Control," In: Shah SP, Ahmad SH, Editors. High Performance Concrete and Applications. London: Edward Arnold, pp. 1-26.

Nevile, A.M. and Brooks, J.J., 2001, "Concrete Technology," Prentice Hall, England, Revised Edition.

OS7:2001 : Ordinary Portland Cement; Specification. Ministry of Commerce \& Industry, Directorate General for Specifications \& Measurements. Oman.

OS2:1982 : Natural aggregate; Specification. Ministry of Commerce \& Industry, Directorate General for Specifications \& Measurements, Oman.

Toutanji, H. and El-Korchi, T., 1995, "The Influence of Silica Fume on the Compressive Strength of Cement Paste and Mortar," Cement and Concrete Research. Vol. 25(7), pp. 1591-1602. 